\title{
Investment Trends in Hyderabad, Pakistan
}

\author{
Vishnu Parmar ${ }^{*}$ and Dr. Amanat Ali Jalbani \\ SZABIST \\ Karachi, Pakistan
}

\begin{abstract}
:
The investment trend in Pakistan fluctuated from province to province, urban to rural, and urban to urban. Small cities of yesteryears have emerged as big cities like Gujranwala, Gujrat, Sialkot, Multan, Rawalpindi, and Faisalabad, while some major centers of trade and business in the past like Thatta, Bhanbhore, Shikarpur, Khairpur, and Hyderabad have ruined. Hyderabad, the second largest city of the province and sixth in the country had flourished in Large Scale Manufacturing until 1980s. Today, the city is loosing its glorious past, the existing units are converting into sick, and the new investment is stagnant. This research paper focuses on the investment trends in Hyderabad, and identifies some causes and consequences of the trend.
\end{abstract}

\section{INTRODUCTION}

\subsection{An Overview of Industrialization in Pakistan}

Pakistan, the only nuclear state in the Muslim World is basically an agricultural country. It is widely accepted that no country has developed economically solely on the basis of agriculture. Therefore, the central pillar of Pakistan's development strategy over the last fifty six years has been industrialization. Pakistan is one of the few developing countries which have successfully used the vehicle of industrialization and made the spectacular progress especially in large scale manufacturing. But this rapid growth of $50 \mathrm{~s}$ and $60 \mathrm{~s}$ could not be maintained in the later decades mainly because of unfriendly government policies, uncontrolled law \& order situation etc. But this situation is not similar in all the provinces. Some have progressed well while some have not.

\subsection{Problem Statement}

The major focus of the study is the Large Scale Manufacturing Units (LSMs) at SITE Hyderabad. The investment trends in Pakistan, Sindh, and in Small Scale Manufacturing have also been discussed. For the purpose of this study the following research questions have been post:

1. What is the investment trend in LSMs in Hyderabad?

2. What are causes and consequences of this trend?

\subsection{Research Methodology}

This is a qualitative research. The data has been collected through primary and secondary sources. The primary data has been gathered through the personal interviews based on semi-structured questionnaires. Following groups of respondents have provided the data / information for the study: owners/heads of the manufacturing units/business community, politicians, academics, and officials from Hyderabad Chamber of Commerce.

Various government publications, research journals, magazines, reports, and Internet sources have been used for secondary data.

\section{INDUSTRIALIZATION IN PAKISTAN}

Pakistan's industrial and economic growth performance up to late 1960's was phenomenal. From 1947 till 1958, the country managed the growth rate of GDP over $3 \%$ in the early years, and $23.6 \%$ in large scale manufacturing in the later years. It remained up to $9.3 \%$ until 1960. During the Ayub regime (1958-1968), agriculture grew at a respectable rate of $4.1 \%$, manufacturing at $9.1 \%$, and trade by $7.3 \%$. GNP growth rates hovered the $6 \%$ through out the decade. The center piece of Ayub's economic strategy was the commitment to the rapid industrialization and the green revolution, [1]. The legacy of Ayub's era is the increased disparity in income across the different regions; particularly the central Punjab and Karachi were permitted to grow at the expense of the rest of the country.

From 1968 to 1977 , the performance of economy was the worst in Pakistan's history in many respects. The GNP growth rate was 5\%, agriculture average annual growth rate was $2.3 \%$, and manufacturing had $3.2 \%$. The most dramatic decision of the Bhutto regime was the nationalization of large private manufacturing and financial institutions. [2] The Zia regime from 1977 till 1988 began to deregulate and liberalize the economy to encourage private-sector investment [3]. The post Zia period from 1988-1999 proved to be more consistent in its policy stance towards liberalization and, particularly, privatization of public enterprises. In 1989, the efforts of Benazir Bhutto's government to establish a Board of Investment for laying down the policy guidelines of affecting industry, and in 1990, a series of policy reforms to stimulate investment in manufacturing by the government of Nawaz Sharif and the IMF/World Bank's Structural Adjustment Program (SAP) for the enhancement of growth by encouraging the private sector including the opening of Public investment areas like power generation, commercial and development banking and air \& sea transport large scale manufacturing sector managed an impressive growth of $7.4 \%$ in 1991/92 [2].

* Institute of Business Administration, Sind University, Jamshoro, Pakistan 
The present regime of General Pervaiz Musharaf has shown satisfactory progress. The economy's current growth rate is 5.1\% in FY 2004 and expected rate for FY 2005 is $5.8 \%$. This has substantially improved the prospects of the industry. The large scale manufacturing sector, especially the textile industry, is expected to grow by $8 \%$ to $9 \%$ in the next two years [4].

\section{INVESTMENT TREND IN SINDH}

Sindh has been industrially developed since centuries. Karachi, Hyderabad, Thatta, Sehwan, Bubak, Hala, Nasarpur, and Gambat have been the prominent business and trade center. Small industries had remarkable development during the Kalhora and Talpur eras [5].

After partition, Sindh played the major role in the early industrialization of the country. Following table presents the detail of establishments in Sindh and its share in Pakistan's economy:

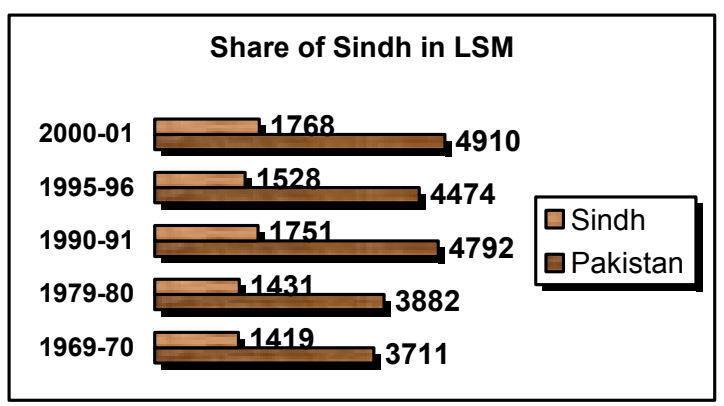

Source: Federal and Sindh Bureau of Statistics 2003

The above table and chart presents the bright picture of industrialization in Sindh. But this healthy trend did not reach to the under-developed areas of the province. The vast difference between industrialization in three major cities of Sindh is presented in the following Table \& Chart:

Table 2: Comparative Analysis of LSMs in Karachi, Hyderabad, \& Sukkur
\begin{tabular}{|c|c|c|c|c|}
\hline Years & Sindh & Karachi & Hyderabad & Sukkur \\
\hline $1970-71$ & 1534 & 1148 & 129 & 64 \\
\hline $1975-76$ & 1357 & 1208 & 66 & 25 \\
\hline $1976-77$ & 1387 & 1245 & 68 & 23 \\
\hline $1977-78$ & 1402 & 1192 & 80 & 32 \\
\hline $1978-79$ & 1435 & 1197 & 85 & 32 \\
\hline $1979-80$ & 1431 & 1206 & 81 & 26 \\
\hline $1980-81$ & 1713 & 1304 & 100 & 40 \\
\hline $1981-82$ & 1566 & 1211 & 90 & 44 \\
\hline $1982-83$ & 1646 & 1181 & 94 & 59 \\
\hline $1983-84$ & 1567 & 1140 & 86 & 46 \\
\hline $1984-85$ & 1669 & 1193 & 100 & 62 \\
\hline $1986-87$ & 1763 & 1297 & 96 & 69 \\
\hline $1987-88$ & 1734 & 1268 & 89 & 67 \\
\hline $1988-89$ & 1726 & 1238 & 94 & 63 \\
\hline $1989-90$ & 1719 & 1240 & 90 & 60 \\
\hline $1990-91$ & 1751 & 1273 & 89 & 48 \\
\hline $1991-92$ & 1695 & 1219 & 92 & 57 \\
\hline $1995-96$ & 1528 & 1061 & 69 & 36 \\
\hline $2000-01$ & 1768 & 1218 & 88 & 31 \\
\hline
\end{tabular}

The above data shows unequal industrialization trend in the province; Karachi's share as the highest is visible.

\section{INVESTMENT TREND IN HYDERABAD}

\subsection{Historical background of Hyderabad}

Hyderabad is one of the oldest cities of South Asia. This land was conquered by the Great Alexandra in the year 327BC. This city remained the capital of Sindh under the Talpur rulers [6]. Hyderabad district spreads over 5,519 square kilometers with an average annual growth rate of $2.02 \%$. The rural population of the district is $49.19 \%$ and urban population is $50.81 \%$. The literacy ratio of the district is $44.35 \%$ [7]. Hyderabad is the second largest city of the province, and occupies sixth position in the country. The current population of Hyderabad is 13.6 million [8].

\subsection{Investment trend in Hyderabad}

Hyderabad from the time immemorial has been the regional market for grains, leather, gold, jewelry, glass, ornamented silks, silver \& gold works, and lacquered ware, arms, ammunition, earthen-ware, iron-ware, cloth, tanned leather, and dairies. Skilled workers of Hyderabad were famous all over the region and even won many prizes at the Industrial exhibitions of Europe. During the Mirs and British rules, the development of trade and commerce was attributed to "Sindh Workers" popularly known as "Sindh-Worki". There were about 5000 workers who used to travel for business in different parts of the world and brought the wealth for the development of Hyderabad city particularly Hirabad [9].

The history reveals that about a century ago, Hyderabad had been the major trade center. People migrated to this city from other parts of the country because of better employment opportunities and abundant resources. Most of the industrial units at that time were of small scale; the highest number of units belonged to the textile sector.

With the establishment of Sindh Industrial Trading Estate (SITE) in 1950 in Hyderabad, a new chapter of industrialization emerged. Up to 1980 s various large industrial units like poultry form \& feed, textile, glass bangles, daal mills, cotton waste, flour mills, pharmaceuticals, engineering, food, paper cardboard \& packages, ginning \& oil, ice \& cold storage, oil, cement, blade, tannery, agricultural products, automobiles, confectionery, rice mills, RCC pipes, electronics, seed mill, steel factory, and other miscellaneous were established.

Interestingly, there were no sick units until 80s. There were 27 and 64 LSM units in 50s and 60s respectively. All were in operation. At present there are total 84 sick units at Hyderabad SITE, 66 are in LSM, while the rest are of small size and commercial units. At province level the number of sick units are 150. Until 1997, there were around 30 sick units LSM, while other 36 units have been closed down just during the last five years. [10] 
The following table presents the current position of operating and sick industrial units at Hyderabad SITE.

Table 3: Operating and Closed Units at SITE Hyderabad (2004)
\begin{tabular}{|l|c|c|c|}
\hline Industries & $\begin{array}{c}\text { Operatin } \\
\text { g Units }\end{array}$ & $\begin{array}{c}\text { Closed } \\
\text { Units }\end{array}$ & $\begin{array}{c}\text { Total } \\
\text { Units }\end{array}$ \\
\hline Textile & 18 & 7 & 25 \\
\hline Glasses / Bangles & 23 & 9 & 32 \\
\hline Cotton Waste & 11 & 4 & 15 \\
\hline Cotton Ginning & 2 & 3 & 5 \\
\hline Rice/Dal/Flour Oil & 55 & 18 & 73 \\
\hline Cement & -- & 1 & 1 \\
\hline Spinning & 3 & -- & 3 \\
\hline Weaving & 4 & 1 & 5 \\
\hline Pharmaceutical & 4 & 1 & 5 \\
\hline Lime & 3 & 1 & 4 \\
\hline Steel \& Iron & 3 & 3 & 6 \\
\hline RC Pipes & 4 & 2 & 6 \\
\hline Beverages & 2 & 2 & 4 \\
\hline Ghee & 2 & 2 & 4 \\
\hline Gases & 1 & 4 & 5 \\
\hline Refrigeration & 6 & -- & 6 \\
\hline Motor Cycles & -- & 1 & 1 \\
\hline Confectionery & 3 & -- & 3 \\
\hline Carpet & 7 & -- & 7 \\
\hline Petrol Pumps & 17 & 4 & 21 \\
\hline Agriculture & 2 & 1 & 3 \\
\hline Engineering & 2 & 1 & 3 \\
\hline P. Form & 22 & 3 & 25 \\
\hline Food & 23 & 14 & 37 \\
\hline Commercial Units & 84 & 307 \\
\hline Total & 23 & & \\
\hline Compiled based on data provided by Chief Engineer, Hyderabad SITE. \\
\hline
\end{tabular}

The number of sick units has grown in the last 25 years and there has been no investment in the city which shows a declining trend of industrialization in large manufacturing units. This trend has affected various industries; the renowned glass industry is at the verge of death which has about 300,000 people associated with it. The famous shoe-making industry has weakened; woolen textile industries like carpets, rugs, and blankets have also closed down. Zeal Pak Cement factory's operation is limited to one turbine only. Tullo Banaspati Ghee, Cafcot Textile Mills, and Coca Cola beverages have also closed down.

Although LSMs have been facing trouble, the increasing number of power looms Hyderabad is reflecting some positive trend in small industry since 1970s. Today there are 7800 power looms at Paretabad Hyderabad as compared to 1800 power looms in 1990 . The main reason, as widely believed, is the nationalization policy of the early $70 \mathrm{~s}$ has energized this informal sector of the economy. Furthermore, the financial/ credit facilities, and marketing and technological training by the Sindh Small Industrial Corporation have made the small scale or the cottage industry more attractive. These incentives for the SSMs and the bottlenecks of LSMs made the small sector more attractive for investors. Thus the entrepreneurs moved from LSMs to SSMs.

\subsection{Major Causes of the Declining Investment Trend}

Based on discussion and focus group interviews, the following have been identified as major causes of decline in investment trend in Hyderabad.

1. Ethnic riots among different groups, particularly between Sindhis and Mohajirs during the late 80s and early 90s have drawn away the investment from Hyderabad. Constant curfews, strikes, protests and shut downs in the city prompted bias to move to other market. All of this also led to the establishment of rural markets of Sukkur, Moro, Nawabshah, and Mirpurkhas.

2. Since the construction of the Super-Highway, traders prefer to cater to Karachi's larger markets.

3. Poor infra-structure facilities especially the damaged roads, drainage systems, scattered wastage mostly disposed off by the Hyderabad Municipal Corporation, and unannounced load-shadings have made the lives of the industrialists miserable.

4. Another factor is the ineffective law and order situation and high interventions of police besides other extortionist groups who take monthly Bhattas.

5. Industrialists believe that government has unfair policies on the allotment of industrial plots and the transfer fee of industrial units at Hyderabad SITE. The government charges Rs. 300,000 to transfer the plot to any new owner in Hyderabad. Comparatively, the transfer fee in only Rs. 30,000 at Kotri, and Rs 200,000 in Karachi.

6. Higher taxation is a common problem for all the industrialists around the country and the investors of Hyderabad are no exceptions.

7. Insufficient basic facilities like good educational institution, good hospitals, parks, clubs and other facilities of entertainment are also major cause of discouragement. This factor plays the role like double edge sword. On one hand it keeps the outsiders away from the city and on the other it motivates the local people to migrate to other areas for the obvious reason of better living.

\subsection{Consequences}

The consequences of this declining investment trend in Hyderabad are as under:

1. The brain drain is very high; intellectuals, literate, and other people are migrating to other cities for a better living.

2. The incremental rate of unemployment reduces the savings, consumptions, and increases poverty. The 
vicious circle of poverty is continuously enlarging and strengthening.

3. Government loses the revenues, and may need to spend huge amount of resources to develop other areas.

4. Investors are losing their trust in government.

5. On the social front culture and art cannot be promoted due to the absence of intellectuals.

6. The population and resource pressures on other big cities like Karachi and Lahore will increase.

7. Unemployment is also the major cause of increasing crime rates, as the free people indulge themselves in various crimes like robbery, pocket picking, and even murder to meet the basic needs of their livelihood.

8. Literacy rate decrease because of no employment opportunities, and low income.

\subsection{Suggestions}

Following are the few suggestions which need to be considered by the concerned authorities for improvement in the situation:

1. Government must provide the security, better infrastructure facilities, and easy documentation process through one window operation. There is need to restore the faith of the investors. Government must adopt the fair and unbiased policy.

2. Necessary actions must be taken to improve the poor law and order situation.

3. The open plots of Hyderabad SITE must be reallotted, and the once already allotted should be properly utilized.

4. The city is badly in need of a master plan. Old drainage system, narrow roads, small water reservoirs, and almost all other basic facilities never meet the demand. This is possible through the special package for Hyderabad.

5. A fair judicial system must be developed, as it will bring political stability and economic prosperity on the whole.

\section{CONCLUSION}

The revival of a few large industrial units recently in Hyderabad has brought some hope to the investors. The present government has been able to improve the law and order situation in Hyderabad which has led to a favourable response from industrialists. The recent revival of Bajwa Textile Mill (sick unit), the newly established Al-Noor cooking oil plant, the forth coming projects of foods and beverages, and automobiles by Fateh Group may change the direction, and the city may once again flourish like the past.

\section{REFERENCES}

[1] Ishrat Hussain, Oxford, [1996] "The Economy of an Elitist state"

[2] Zaidi S.Akbar, Oxford, [1999], "Issues in Pakistan's Economy"

[3] Ishrat Hussain, Oxford, [1996] "The Economy of an Elitist state"

[4] Asian Development Bank, report, April 28, [2004]

[5] Khaskhely, Ghulam Hussain, Institute of Sindhology [1976], "Economy of Sindh"

[6] Khan Ishrat Ali, Idarak Publication, [2002], "Hyderabad"

[7] Population Census Organization Statistic Division, Govt. of Pakistan, [1999], "Census Report of Hyderabad"

[8] World Gazetteer, [2004], "Largest Cities of the World" www.world-gazetteer.com

[9] Bohra, Dr. Qamaruddin, Royal Book Company, 2000, "City of Hyderabad Sindh, 712-1947

[10] Interview with Mr. Abdullah Soomro, Chief Engineer, SITE, Hyderabad 